\title{
GENERALIZING SURVEY RESULTS FROM STUDENT SAMPLES: IMPLICATIONS \\ FROM SERVICE RECOVERY RESEARCH
}

\section{Chihyung Ok, Ph.D.}

Assistant Professor

Department of Hotel, Restaurant, Institution Management \& Dietetics

Kansas State University

148C Justin Hall

Manhattan, KS 66506-1404

USA

Phone: (785) 532-2207

Fax: (785) 532-5522

Email: cok0307@,ksu.edu

\section{Carol W. Shanklin, Ph.D., R.D.}

Interim Dean of Graduate School and

Professor, HRIMD

Kansas State University

103 Fairchild Hall

Manhattan, KS 66506-1404

USA

Phone: (785) 532-7927

Fax: (785) 532-2983

Email: shanklin@ksu.edu

\section{Ki-Joon Back, Ph.D.}

Associate Professor

Conrad N. Hilton College of Hotel and Restaurant Management

University of Houston

$$
\text { 213-J }
$$

Houston, TX 77204-3028

USA

Phone: (713) 743-2530

Fax: (713) 743-2575

Email: kback@central.uh.edu 


\title{
GENERALIZING SURVEY RESULTS FROM STUDENT SAMPLES: IMPLICATIONS FROM SERVICE RECOVERY RESEARCH
}

\begin{abstract}
Using college students as research subjects in consumer research may or may not be appropriate. This paper discusses external validity of research findings using student subjects as surrogates for consumers in experimental, particularly scenario based, studies. A study that investigated differences between a student sample and a customer sample in response to service experience is described. Results were mixed. No significant mean differences were found in complaint intention, preference to complain to an employee or a manager, overall satisfaction, and revisit intention toward service providers. However, significant discrepancies were observed in testing the role of initial overall satisfaction in evaluating recovery satisfaction and in the relative importance of dimensions of justice. For both student and non-student groups, regardless their recovery satisfaction were positive or negative, initial overall satisfaction was a stronger predictor for post-recovery overall satisfaction than recovery satisfaction.
\end{abstract}

Key Words: generalizability, student sample, complaint intentions, service recovery, satisfaction 


\section{INTRODUCTION}

Most hospitality and tourism researchers want empirical findings meaningful to practitioners, helping them make effective decisions and improve their business practices. Consumer attitudinal and behavioral responses during and/or after service experiences are important in verifying cause and effect relationships. However, many consumer behaviors, especially those in response to service experiences, are not closely observable or measurable. Thus, researchers in hospitality and other service marketing fields use pencil-and-paper experiments extensively to identify customer responses to various treatments (Goodwin \& Ross, 1992; Mattila, 1999, 2001; Sundaram, Jurowski, \& Webster, 1997). This method allows researchers to easily manipulate the nature of the service, the extent of the problem, and situational factors by providing different levels of stimuli (Singh \& Widing II, 1991).

For both applied and theoretical experiments, research findings should be generalized to other populations and settings (Lynch, 1982; Campbell \& Stanley, 1963). However, many marketing and consumer behavior studies in hospitality and service settings have used college students as subjects in scenario based experiments (Goodwin \& Ross, 1992; McCollough, 2000; Sundaram et al., 1997; Webster \& Sundaram, 1998). Using student subjects in such experimentations has caused some disagreement about whether using student samples is appropriate. Many research articles published in academic journals have been criticized as the "science of the sophomore" because of their heavy reliance on college students as surrogates for consumers (Hampton, 1979; James \& Sonner, 2001). Despite the criticism, student samples as surrogates for non-student consumers are still widely used in consumer attitudinal and behavioral studies.

One major problem in the discussion of generalizability is that no commonly accepted 
standards exist for what characterizes proof of external validity (Mitchell, 1985). Little effort has been devoted to the issue in hospitality and tourism settings. Thus, this paper seeks to assess how well research findings based on student subjects apply to other customers. The authors first discuss the external validity of research findings using student subjects as surrogates for consumers in scenario-based experimental studies. Results of this study on significant differences between student samples and customer samples in response to service experience are followed.

\section{REVIEW OF LITERATURE}

\section{Experimentation and Validity Issue}

Experimental researchers attempt to discover causal relationships between treatment variables and dependent variables (Cook \& Campbell, 1979; Perdue \& Summers, 1986). If the manipulated independent variable(s) makes a difference to the dependent variables, researcher(s) will conclude that the manipulation contributes to the differences. Applied in marketing and consumer behavior studies, inferences drawn from the causal relationships enable researchers to provide a series of recommendations for making effective decisions and for improving business practices. This increased use of experimentation has also encouraged hospitality researchers to investigate casual relationships and to refine theories (Lynn \& Lynn, 2003; Oh \& Parks, 1997).

Interpretable, meaningful results from experiments require two broad categories of validity: internal validity and external validity (Cook \& Campbell, 1979). Ruling out extraneous factors (background factors) is an important task in discovering whether a treatment(s) makes a difference in dependent measures (Cook \& Campbell, 1979). When these threats to internal validity [history, instrumentation, etc.; cf. Cook and Campbell (1979) for more discussion of common threats to internal validity] are not clearly ruled out, alternative explanations of the 
relationship between the cause and the effect exist (Mitchell, 1985).

External validity, on the other hand, refers to "the approximate validity with which we can infer that the presumed causal relationship can be generalized to and across alternate measures of the cause and effect and across different types of persons, settings, and times" (Cook \& Campbell, 1979, p.37). Selecting research subjects is relevant to how well research findings apply beyond the subjects themselves of a specific study because of the threat of interaction of selection and treatment (Cook \& Campbell, 1979). An appropriate sampling strategy, therefore, ensures external validity. Convenience sampling is popular among researchers to get a set of data in consumer research, but convenience samples should be related to the target population, with an adequate sample size for analysis and a representative sample of the population (Ferber, 1977).

\section{Student Samples as Experimental Subjects}

Generalizability of research findings derived from student subjects in an experimental setting to "real world subjects" has been recognized, examined, and debated in a variety of disciplines for more than five decades (Peterson, 2001). Convenience and the minimal costs are compelling incentives for researchers, particularly academic researchers to use student samples as data sources (Gordon, Slade, \& Schmitt, 1986; Hampton, 1979; Hawkins, Albaum, \& Best, 1977). However, these features do not justify using student samples for an experimental study instead of other customer groups. College students are not representative of the general population but are a selected group (Gordon et al., 1986; Landis \& Kuhn, 1957). There are both proponents and opponents of using student samples as experimental subjects.

Proponents. One group of researchers argue that using students as experimental subjects does not falsely represent research findings and conclude that students are reasonable surrogates for other consumers. Using student samples in marketing and consumer behavior studies is 
justified for a number of reasons. In theory application studies, a homogeneous respondent population is preferred (Lynch, 1982; Winer, 1999). Lynch (1999) suggested that findings from a single-real world setting with sets of "real" people are not more generalizable than findings from a single setting with student subjects. He stated that research using somewhat random sampling method from the true population of interest (heterogeneous "representative" samples to increase external validity) leads to inflated "error" variance because background factors have been ignored. Students as research subjects, however, display similar characteristics. Thus, college students exhibit "less variation within a scale (smaller standard deviations) and more consistency across scales (higher correlations) than do non-students" (Peterson, 2001, p. 454). These facts translate into strong hypothesis tests because extraneous variation associated with college students is less than that in non-students groups (Lynch, 1982; Peterson, 2001). Students have strong cognitive skills that prevail in laboratory experiments (Sears, 1986; James \& Sonner, 2001). Further, the use of student samples can be justified on the grounds that student respondents are "real-life consumers" and familiar with the hospitality and tourism context (Collie, Sparks, \& Bradley, 2000; Mattila, 2001).

Opponents. The use of student subjects has been opposed because students may not be representative of general customers. Students and non-students differ in skills, personality traits, and experience, and student samples usually come from a very narrow age range and from the upper levels of educational background (Sears, 1986; Wells, 1993). Moreover, students tend to comply with authority and cooperate with researchers, who are often teachers in their academic environment, which may skew responses and, thus, findings (James \& Sonner, 2001; Peterson, 2001; Sears, 1986). Such characteristics may lead students to respond to treatments differently than non-students and thus change the direction of relationships or the strength of effects. 
Therefore, research findings may not be applicable to general customer groups.

\section{Research Findings in the Literature}

Study findings in the literature are somewhat mixed. Students can be reasonable surrogates for consumers in studying the information and decision-making processes (Ashton \& Kramer, 1980). Many studies have confirmed, however, that student samples differed from nonstudent samples. For example, James and Sonner (2001) suggested that, in advertising, generalizing research findings from college students to other market segments is limited.

Gordon et al. (1986) reviewed thirty-two studies where both students and non-students participated as subjects under identical conditions. Among 22 quantitative studies, 16 studies reported at least one statistical, between-subject difference. However, many earlier studies compared student samples as the direct surrogate of a distinct group. For example, Cunningham, Anderson, and Murphy (1974) found significant differences in the means of socio-psychological variables between household samples and student samples. They concluded that students are not good surrogates for household consumers' socio-psychological attributes. Such findings support those who oppose research using college students as surrogates for non-student consumers. However, a dramatic shift has occurred in the characteristics of students. For example, student gender ratios have changed, and the percentage of non-traditional students has increased. Peterson (2001) discussed findings of behavioral and psychological relationships and reported results of a second meta-analysis on homogeneity and effect sizes from several meta-analyses.

\section{An Experimental Study}

Using student samples in scenario based experimental research in hospitality and tourism studies has proliferated. However, no attempt has been made to ascertain if significant discrepancies exist between student samples and customer samples by directly comparing the 
two samples. This study specifically employed a service failure and recovery situation to test for significant discrepancies between student samples and customer samples.

Researchers have indicated that demographic characteristics are related to complaint behavior (Lam \& Tang, 2003). Three characteristics are salient in student samples: age, level of education, and level of income. Lam and Tang (2003) found that the younger respondents were more likely to express their complaints in various ways than the older groups. They also found that the higher income groups were more likely to undertake various types of complaint behavior and were more likely to complain to management when they sought redress than other groups. This study tests for significant differences in complaint intention and in to whom students and non-students prefer to complain.

Researchers have indicated that customers who are satisfied with service providers are apt to perceive the recovery performance as better. This might happen because customers who have experienced quality service with selected providers may hold a high level of tolerance and/or a low level of recovery expectation (Hess, Ganesan, \& Klein, 2003; Ruyter \& Wetzels, 2000). This study tests for differences in recovery outcome evaluation among different levels of customer initial satisfaction after controlling for recovery scenarios. The test may answer the following question for service providers: "When experiencing a service problem, will your highly satisfied customers evaluate your recovery efforts more favorably than customers who are merely satisfied?"

In an effort to redress customers' voiced complaints, service providers try to recover customers' perceived inequity by providing extra inputs. According to the three dimensional view of justice, consumer evaluation of recovery efforts is determined by the perceived fairness of the outcome (distributive justice); the perceived fairness of the manner in which the complaint 
is handled (interactional justice); and the process by which rewards are dispensed (procedural justice; Blodgett, Granbois, \& Walters, 1993; Blodgett, Hill, \& Tax, 1997). The three dimensions of justice collectively account for more than $60 \%$ of the explained variation in encounter satisfaction (Smith, Bolton, \& Wagner, 1999). Please refer to the above-mentioned studies for more theoretical foundations. This study tests the effect of the three dimensions of justice on recovery satisfaction to confirm the justice theory.

Managers of service entities, in addition, may be interested in the relative importance of the dimensions of justice. However, generalizing findings from student samples to specific populations may not be appropriate because students may give more weight to certain attributes than other restaurant customer groups do (Smith \& Bolton, 2002). For example, students give more weight to monetary compensation than other segments of customers in evaluating service recovery. In response to the proposed query, this study tests the relative weight of three dimensions of justice to see if they were equally effective in recovery satisfaction for both customer group and student group.

Recovery satisfaction can have more influence on post-recovery overall satisfaction than initial overall satisfaction. Asymmetric disconfirmation theory suggests that negative performance affects more than positive performance in developing an overall satisfaction judgment. Therefore, an unsatisfactory transaction affects overall satisfaction more heavily than a satisfactory one (Maxham \& Netemeyer, 2002). This study tests the relative weight of initial overall satisfaction and recovery satisfaction on post-recovery overall satisfaction after classifying both groups into either negative or positive transactional evaluation.

\section{METHODOLOGY}

\section{Instrument Development and a Pilot Test}


To develop realistic experimental scenarios, 43 undergraduate students in a hospitality program were asked to describe service failures and recovery efforts that they had experienced at casual dining restaurants. The results were similar to the typology of service failures and recovery efforts reported in previous studies (e.g., Kelley, Hoffman, \& Davis, 1993; Hoffman, Kelley, \& Rotalsky, 1995). A service failure scenario (being served overcooked steak) was developed. Eight recovery scenarios were described; dimensions of justice were manipulated into two levels each (high versus low). Participants were randomly assigned one of the eight recovery scenarios. Each scenario was identical except for the description of manipulations. An example (high interactional justice, low procedural justice, and low distributive justice) is noted below: After you explained the problem to the server, he sincerely apologized for the problem. He said that he could not do anything about the problem and would get a manager to resolve it. After 10 minutes, the manager approached you and apologized for the problem. The manager asked you what the problem was and you had to re-explain the problem. She also explained why the problem happened. She informed you that another steak would be served. No other compensation was offered. She asked if there was anything else that she could do to serve you better.

Following the suggestion of Smith and Bolton (1998), participants were asked to name a casual restaurant that they visited recently rather than their favorite restaurant. By doing so, customers' initial attitude toward restaurants should be more varied. Participants were asked to read the scenario and to assume that the situation had just happened to them in a restaurant.

Complaint intentions were measured by asking participants the magnitude of their intention to complain when they experienced poor service. Participants were asked if they preferred to complain to a manager or an employee. For the following measures, respondents 
were asked to indicate their level of agreement on multi-evaluative items anchoring from 1) strongly disagree to 7) strongly agree.

Initial overall satisfaction and revisit intentions were measured before presenting the failure scenario and one of the recovery scenarios. The initial and post-recovery overall satisfaction scale asked about overall satisfaction with the particular restaurants that they named. Revisit intentions were evaluated by assessing whether respondents were likely to dine out at the particular restaurant in the near future.

Evaluations of the perceived outcome fairness measured distributive justice; the perceived fairness of procedures and timely responsiveness measured procedural justice; and apology, explanation, and concern toward customers measured interactional justice. Recovery satisfaction was measured after a service failure scenario and a service recovery scenario were presented. Particular emphasis was given to the statements like, "In my opinion, the restaurant provided a satisfactory resolution to the problem on this particular occasion," because service recovery satisfaction measured a transaction evaluation.

A pre-test was conducted to refine the research instrument. Graduate students and faculty members (approximately 15) in a hospitality program were asked to evaluate the survey instrument. Participants were asked to identify any ambiguous questions, measurements, and scenarios. Such changes as modifying wording, deleting unnecessary questions, and underlining negative verbs were made accordingly.

Following the pre-test, a pilot test of the instrument ensured manipulations of justice dimensions and assessed the reliability and validity of the measurements. Undergraduate students (46 forty-six female and 50 fifty male) enrolled in a hospitality management class taken by both majors and non-majors were randomly assigned to one of the eight scenarios. The mean age of 
the participants was 20.89 years $(S D=2.09)$. Approximately $31 \%(n=30)$ of the respondents were hospitality majors. Reliability of the measurements was estimated using Cronbach's coefficient alpha, and values were well above the suggested cutoff of .70 (Nunnally, 1978). No changes were made in the instrument for the final study. Table 1 lists the measurement items adopted and sources cited and measurement reliabilities.

\section{Insert Table 1 Here}

\section{Subjects and Data Collection}

Gordon et al. (1986) contend that the most persuasive evidence of generalizability of research findings using student subjects can be found in published empirical studies that collected data from both student and non-student subjects under identical experimental conditions. Using Gordon et al.’s (1986) recommendation, this study selected two convenient sample groups: restaurant customers and undergraduate students at a Midwestern university. For the non-student group, 600 copies of a survey packet were distributed to individuals who showed interest in participating in the study during community fund raising events, educational programs, or regular meetings of participating groups. A total of 286 usable responses were obtained from the 308 questionnaires returned (47.67\% usable response rate). Student participants were drawn from courses in a hospitality program at a Midwestern university. To obtain data from various disciplines, elective courses were preferred, and data were collected during classes. Among 277 responses collected from student participants, 11 responses were excluded because of missing values and/or not following instruction, such as naming quick service restaurant, and 266 subjects' responses were retained for further data analysis.

\section{DATA ANALYSIS AND RESULTS}

The customer respondents consisted of $60.5 \%$ female $(n=173)$ and $38.5 \%$ male $(n=$ 
110). The sample was primarily Caucasian/white $(84.3 \%, n=241)$. The mean age of the customer sample was 42.52 years $(S D=16.45)$. The age category of 45 to 54 accounted for the most (22.7\%) respondents, and the 65 and over group was the lowest $(9.4 \%)$.

Of the 266 student responses obtained, 59.8\% $(n=159)$ of sample included students form more than 30 majors; $40.2 \%(n=107)$ were hospitality majors. The student respondents consisted of $40.2 \%$ male $(n=107)$ and $57.1 \%$ female $(n=152)$. Most of the students $(89.5 \%$, $n=238)$ were Caucasian/White. The mean age of the student participants was 21.33 years $(S D=$

2.14). The age of the student respondents ranged from 18 to 38 , and $92.5 \%$ were between 18 and 24 years old. Table 2 presents further information on the characteristics of participants.

\section{Insert Table 2 Here}

\section{Complaining Intentions}

To determine the significance of mean differences of complaint intentions of the two groups, independent-samples $t$-tests were performed. The non-student and student groups showed no significant mean difference in their complaint intention (mean difference $=.02, t=-$ $.18, p=.859$ ) when they experienced poor service. The non-student group was more likely to complain to managers $($ mean $=4.76)$ than the student group $($ mean $=4.50)$, but the mean difference $(t=1.86, p=.064)$ was not statistically significant. As Peterson (2001) pointed out, the student group did have smaller standard deviations than the non-student group for both measures. Table 3 provides means and standard deviations of measures. Chi-squared tests of independence also were performed to see the relationship between groups (non-students versus students) and complaint intentions; no associations were found $\left[\chi^{2}(6, N=551)=4.795, p=.570\right.$ for complaint intention, and $\chi^{2}(6, N=552)=6.027, p=.420$ for intention to complain to a manager or an employee]. 


\section{Insert Table 3 Here}

\section{Initial Overall Satisfaction and Revisit Intention}

Before testing the effect of initial overall satisfaction on recovery evaluation, for restaurants they had recently visited, the levels of initial overall satisfaction and the revisit intentions of the student and non-student samples were evaluated. Overall, the two groups showed no significant mean difference in initial overall satisfaction (mean difference $=.077, t$ $=.703, p=.483$ ) and revisit intention (mean difference $=.107, t=.941, p=.347$ ). Because having participants name restaurants might bias the results, further analyses were performed on

the two most frequently named restaurants from both groups. As shown in Table 4, no significant mean differences were found between the two groups for each restaurant. However, note that non-student customers have higher overall satisfaction and revisit intention toward brand A restaurant, and students have higher overall satisfaction and revisit intention toward brand B restaurant.

\section{Insert Table 4 Here}

\section{Effects of Initial Overall Satisfaction on Recovery Satisfaction}

The ANCOVA (in Table 5) result indicates that the main effects of covariates (the effects of recovery scenarios) on recovery satisfaction were significant $\left(F_{1,278}=107.28, p<.001\right.$ for the non-student group, and $F_{1,260}=63.68, p<.001$ for the student group). The variances explained by the scenarios provided, $\eta^{2}$, were large for both groups $\left(\eta^{2}=.28\right.$ for the non-student group, and $\eta^{2}=.20$ for the student group). The variances explained by initial overall satisfaction were small for the non-student sample (about 3\%) and medium for the student sample (about $8 \%$ ). The findings may indicate that recovery satisfaction, a transactional evaluation in this analysis, is 
largely determined by how service providers respond (in terms of dimensions of justice) to customer complaints.

\section{Insert Table 5 Here}

The main effect of initial overall satisfaction was not significant $(F=4.47, p=.058)$ for the non-student sample. On the other hand, the main effect of initial overall satisfaction was significant $(F=7.75, p<.001)$ for the student sample. The mean of the highly dissatisfied group (3.67) was significantly lower than the mean of both the somewhat satisfied group (4.43) and the highly satisfied group (5.01) at the significance level of .05 and .001 , respectively. Figure 1 portrays means of recovery satisfaction for both groups.

\section{Insert Figure 1 Here}

\section{Roles of Justice Dimensions and Their Relative Importance}

The three dimensions of justice had significant positive effects on recovery satisfaction for both student and customer samples (see Table 6). The three dimensions of justice accounted for a significant amount of the explained variation in recovery satisfaction in both customer and student samples (adjusted $R$-square value of 0.75 and 0.80 , respectively). Although some researchers have indicated that students are different from other customers in their responses to service experiences, this finding may indicate that using students may not be problematic in concluding that proper service recovery efforts through dimensions of justice leads to customer recovery satisfaction.

\section{Insert Table 6 Here}

However, this study did find that using students as a direct surrogate for customers could be misleading for specific research hypotheses/questions. For the customer sample, procedural and distributive justice had the most significant effect on recovery satisfaction, but for the 
student sample, distributive justice had the most significant effect on recovery satisfaction, followed by interactional justice and procedural justice. Therefore, generalizing study findings from the student sample to customers may not be appropriate when measuring the relative importance of dimensions of justice.

For both student and non-student groups, whether their recovery satisfaction was positive or negative, initial overall satisfaction was a stronger predictor for post-recovery overall satisfaction than recovery satisfaction. Table 7 lists standardized coefficients of initial overall satisfaction and recovery satisfaction on post-recovery overall satisfaction. The findings indicate that having student samples to test the relative weight of initial overall satisfaction and recovery satisfaction on post-recovery overall satisfaction may not be problematic.

\section{Insert Table 7 Here}

\section{SUMMARY AND SUGGESTIONS FOR FUTURE STUDY}

This study found that results may be generalized from student samples to customers for theory based overall research hypotheses/questions in service recovery research in a restaurant environment. However, the use of students as a direct surrogate of customers could be misleading for specific research hypotheses/questions in such a context. Therefore, generalizing study findings from student samples to customers may not be appropriate for specific relationships.

This study cannot conclude if the use of student samples as surrogates for non-student customers is appropriate. Indeed, it was not the intention of the study. As Greenberg (1987) pointed out, external validity is not achieved in any one study, but requires evaluating different studies; future researchers can demonstrate generalizability through comparisons. Cumulative knowledge from various researchers and from various methodologies gives meaningful 
information to practitioners (Piccoli \& Wagner, 2003). In other words, meta-analysis of the existing body of literature delivers generalized quantitative estimates for parameters of buyer behavior (Farley, Lehmann, \& Sawyer, 1995). The use of student samples in theory testing and/or applied research does contribute to the body of literature. What researchers desire to generalize, particularly from those studies, are the theoretical explanations and not the particular effects (Calder, Phillips, \& Tybout, 1981). Further, students themselves are a separate and distinct market segment in the restaurant industry, so that a clear distinction should be made to the degree to which findings are applicable to wider populations. As recommended by Cook and Campbell (1979), distinguishing "generalizing to" target populations and "generalizing across" multiple populations is critical. For example, generalizing study findings related to the decisionmaking process from student subjects directly to seniors may not be appropriate. It is clear that researchers should report limitations when extrapolating the results to a particular subgroup.

This study performed comparative evaluations in complaint intentions and service recovery in an effort to provide evidence about generalizing results from student convenience samples to restaurant customers. More studies, therefore, are necessary to provide further enlightenment. Indeed, the study findings are from a single industry setting. Service recovery evaluation, however, is context specific; characteristics of service have significant influence on the evaluation of service recovery efforts (Hoffman \& Kelley, 2000; Mattila, 2001). Research findings from a single study may not help managers make business decisions. Therefore, results of this study alone should not serve as the basis for making operational changes.

Finally, because many student participants in this study are hospitality majors, a series of independent sample $t$-tests were conducted to determine if hospitality students have different attitudes toward restaurants that they named and if they evaluate recovery efforts differently 
from other students. No significant mean differences in complaint intention, distributive justice, procedural justice, interactional justice, recover satisfaction, initial/post-recovery satisfaction, and initial/post-recovery revisit intention were found at the significance level of $p=.01$ in this study. Thus, the authors presented results from based on all student responses. However, it has been suggested that hospitality major students may have potential education bias (Oh, 2000). 


\section{REFERENCES}

Ashton, R.H., \& Kramer, S.S. (1980). Students as surrogates in behavioral accounting research: Some evidence. Journal of Accounting Research, 18(1), 1-15.

Blodgett, J.G., Granbois, D.H., \& Walters, R.G. (1993). The effects of perceived justice on complainants' negative word-of-mouth behavior and repatronage intentions. Journal of Retailing, 69(4), 399-428.

Blodgett, J.G., Hill, D.J., \& Tax, S.S. (1997). The effects of distributive, procedural and interactional justice on postcomplaint behavior. Journal of Retailing, 73(2), 185-210.

Brown, S.W., Cowles, D.L., \& Tuten, T.L. (1996). Service recovery: Its value and limitations as a retail strategy. International Journal of Service Industry Management, 7(5), 32-46.

Calder, B.J., Phillips, L.W., \& Tybout, A.M. (1981). Designing research for application. The Journal of Consumer Research, 8(2), 197-207.

Campbell, D.T., \& Stanley, J.C. (1963). Experimental and quasi-experimental designs for research. Boston: Houghton Mifflin.

Collie, T.A., Sparks, B., \& Bradley, G. (2000). Investing in interactional justice: A study of the fair process effect within a hospitality failure context. Hospitality Research Journal, 24(4), 448-472.

Cook, T.D., \& Campbell, D.T. (1979). Quasi-experimentation: Design and analysis issues for field settings. Chicago: Rand McNally.

Cunningham, W.H., Anderson Jr, W.T., \& Murphy, J.H. (1974). Are students real people? The Journal of Business, 47(3), 399-409.

Farley, J.U., Lehmann, D.R., \& Sawyer, A. (1995). Empirical marketing generalization using meta-analysis. Marketing Science, 14(3), Part 2 of 2: Special Issue on Empirical 
Generalizations in Marketing, 36-46.

Ferber, R. (1977). Research by convenience. Journal of Consumer Research, 4(1), 57-58.

Goodwin, C., \& Ross, I. (1992). Consumer responses to service failures: Influence of procedural and interactional fairness perceptions. Journal of Business Research, 25(2), 149-163.

Gordon, M.E., Slade, L.A., \& Schmitt, N. (1986). The science of the sophomore revisited: from conjecture to empiricism. Academy of Management Review, 11(1), 191-207.

Greenberg, J. (1987). The college sophomore as guinea pig: Setting the record straight. The Academy of Management Review, 12(1), 157-159.

Hampton, G.M. (1979). Students as subjects in international behavioral studies. Journal of International Business Studies, 10(2), 94-96.

Hawkins, D.I., Albaum, G., \& Best, R. (1977). An investigation of two issues in the use of students as surrogates for housewives in consumer behavior studies. The Journal of Business, 50(2), 216-222.

Hess Jr., R.J., Ganesan, S., \& Klein, N.M. (2003). Service failure and recovery: The impact of relationship factors on customer satisfaction. Academy of the Academy of Marketing Science, 31(2), 127-145.

Hoffman, K.D., \& Kelley, S.W. (2000). Perceived justice needs and recovery evaluation: A contingency approach. European Journal of Marketing, 34(3/4), 418-432.

Hoffman, K.D., Kelley, S.W., \& Rotalsky, H.M. (1995). Tracking service failures and employee recovery efforts. Journal of Services Marketing, 9(2), 49-61.

James, W.L., \& Sonner, B.S. (2001). Just say no to traditional student samples. Journal of Advertising Research, 41(5), 63-71. 
Kelley, S.W., Hoffman, K.D., \& Davis, M.A. (1993). A typology of retail failures and recoveries. Journal of Retailing, 69(4), 429-452.

Lam, T., \& Tang, V. (2003). Recognizing customer complaint behavior: The case of Hong Kong hotel restaurant. Journal of Travel \& Tourism Marketing, 14(1), 69-86.

Landis, J.T., \& Kuhn, M. (1957). Values and limitations of family research using student subjects. Marriage and Family Living, 19(1), Proceedings of the Family Research Conference, 100-107.

Lynch Jr., J.G. (1982). On the external validity of experiments in consumer research. Journal of Consumer Research, 9(3), 225-239.

Lynch Jr., J.G. (1999). Theory and external validity. The Journal of Academy of Marketing Science, 27(3), 367-376.

Lynn, A., \& Lynn, M. (2003). Experiments and quasi-experiments: Methods for evaluating marketing options. Cornell Hotel and Restaurant Administration Quarterly, 44(2), 7584.

Mattila, A.S. (1999). An examination of factors affecting service recovery in a restaurant setting. Journal of Hospitality \& Tourism Research, 23(3), 284-298.

Mattila, A.S. (2001). The effectiveness of service recovery in a multi-industry setting. Journal of Services Marketing, 15(7), 583-596.

Maxham, J.G. III, \& Netemeyer, R.G. (2002). Modeling customer perceptions of complaint handling over time: The effects of perceived justice on satisfaction and intent. Journal of Retailing, 78(4), 239-252.

McCollough, M.A. (2000). The effect of perceived justice and attribution regarding service failure and recovery on post-recovery customer satisfaction and service quality 
attitudes. Journal of Hospitality \& Tourism Research, 24(4), 423-447.

Mitchell, T.R. (1985). An evaluation of the validity of correlational research conducted in organizations. The Academy of Management Review, 10(2), 192-205.

Nunnally, J.C. (1978). Psychometric theory. New York, NY: McGraw-Hill, Inc.

Oh, H. (2000). The effect of brand class, brand awareness, and price on customer value and behavioral intentions. Journal of Hospitality and Tourism Research, 24(2), 136-162.

Oh, H., \& Parks, S.C. (1997). Customer satisfaction and service quality: A critical review of the literature and research implications for the hospitality industry. Hospitality Research Journal, 20(3), 36-64.

Ok, C., Back, K., \& Shanklin, C. (2005). Modeling roles of service recovery strategy: A relationship-focused view. Journal of Hospitality and Tourism Research, 29(4), 484-507.

Oliver, R.L., \& Swan, J.E. (1989). Consumer perceptions of interpersonal equity and satisfaction in transactions: A field survey approach. Journal of Marketing, 53(2), 2135.

Perdue, B.C., \& Summers, J.O. (1986). Checking the success of manipulations in marketing experiments. Journal of Marketing Research, 23(November), 317-326.

Peterson, R.A. (2001). On the use of college students in social science reseach: Insights from a second order Meta-analysis. Journal of Consumer Research, 28(3), 450-461.

Piccoli, G., \& Wagner, E.L. (2003). The value of academic research. Cornell Hotel and Restaurant Administration Quarterly, 44(2), 29-38.

Ruyter, K., \& Wetzels, M. (2000). Customer equity considerations in service recovery: A cross-industry perspective. International Journal of Service Industry Management, 11(1), 91-108. 
Sears, D.O. (1986). College sophomores in the laboratory: Influences of a narrow data base on social psychology's view of human nature. Journal of Personality and Social Psychology 51(3), 515-530.

Singh, J., \& Widing II, R.E. (1991). What occurs once consumers complain? A theoretical model for understanding satisfaction/dissatisfaction outcomes of complaint management. European Journal of Marketing, 25(5), 30-46.

Smith, A.K., \& Bolton, R.N. (2002). The effect of customers' emotional responses to service failures on their recovery effort evaluations and satisfaction judgments. Academy of the Academy of Marketing Science, 30(1), 5-23.

Smith, A.K., Bolton, R.N., \& Wagner, J. (1999). A model of customer satisfaction with service encounters involving failure and recovery. Journal of Marketing Research, 36(3), 356-362.

Sundaram, D.S., Jurowski, C., \& Webster, C. (1997). Service failure recovery efforts in restaurant dining: The role of criticality of service consumption. Hospitality Research Journal, 20(3), 137-149.

U.S. Census Bureau (2005). United States Census 2000. Retrieved November 2005 from the World Wide Web: http://www.census.gov/

Webster, C., \& Sundaram, D.S. (1998). Service consumption criticality in failure recovery. Journal of Business Research, 41(2), 153-159.

Wells, W.D. (1993). Discovery-oriented consumer research. Journal of Consumer Research, 19(4), 489-504.

Winer, R.S. (1999). Experimentation in the $21^{\text {st }}$ century: The importance of external validity. Journal of the Academy of Marketing Science, 27(3), 349-358. 
Submitted: August 30, 2007

Fist Revision Submitted: October 19, 2007

Final Revision Submitted: November 28, 2007

Accepted:

Refereed Anonymously 
Table 1 Measurement Items, Sources, \& Reliability

\begin{tabular}{l}
\hline Construct \\
\hline Distributive Justice (Maxham \& Netemeyer, 2002 ${ }^{\mathrm{a}}$; Blodgett et al., 1997, $\alpha=.92$ ) \\
- Although this event caused me problems, the restaurant's efforts to resolve it \\
resulted in a very positive outcome of me. \\
- Given the inconvenience caused by the problem, the outcome I received from \\
the restaurant was fair. \\
- The service recovery outcome that I received in response to the problem was \\
more than fair. \\
- Given the circumstances, I feel that the restaurant offered adequate \\
compensation.
\end{tabular}

Procedural Justice (Maxham \& Netemeyer, 2002 ${ }^{\mathrm{a}}$ )

$.92 \& .91^{c}$

- Despite the hassle caused by the problem, the restaurant responded quickly.

- I feel the restaurant responded in a timely fashion to the problem.

- I believe the restaurant has fair policies and practices to handle problems.

- With respect to its policies and procedures, the employee(s) handled the problem in a fair manner.

Interactional Justice (Maxham \& Netemeyer, 2002 ${ }^{\text {a }}$, Smith et al., 1999, $\alpha=.88-.93$ $.96 \& .95^{\mathrm{c}}$ depending on the industry)

- In dealing with the problem, the restaurant personnel treated me in a courteous manner.

- During effort to resolve the problem, the restaurant employee(s) seemed to care about the customers.

- The restaurant employee(s) were appropriately concerned about my problem.

- While attempting to solve the problem, the restaurant personnel considered my views.

Recovery Satisfaction (Maxham \& Netemeyer, 2002ª \& Brown et al., 1996, $\alpha=.80)$

- In my opinion, the restaurant provided a satisfactory resolution to the problem on this particular occasion.

- I am satisfied with the restaurant's handling of this particular problem.

- I am satisfied with this particular dining experience.

(Initial/Post-recovery) Overall Satisfaction (Oliver \& Swan, 1989, $\alpha=.88-.93$ depending on samples and products ${ }^{b}$ )

$.94 \& .94^{\mathrm{c}}$

- I am satisfied with my overall experience with the restaurant.

- As a whole, I am happy with the restaurant.

- Overall, I am pleased with the service experiences with this restaurant.

(Initial/Post-recovery) Revisit Intention (Maxham \& Netemeyer, 2002 ${ }^{\mathrm{a}}$ \&

Blodgett et al., 1997, $\alpha=.91$ )

Alpha

$.93 \& .92^{\mathrm{c}}$

Irom 
${ }^{a}$ Cronbach's alpha values of measurements adapted from Maxham and Netemeyer's study ranged from .89 to .93 .

${ }^{\mathrm{b}}$ Reported Cronbach's alpha values of the measurements are from the study of Westbrook \& Oliver (1981), from which the authors adopted.

'Cronbach's alpha is listed for the customer group first followed by the student group. For example, Chronbach's alpha values for initial overall satisfaction and post-recovery overall satisfaction for the customer group were .95 and .97 , respectively. For the same measures, Cronbach's alpha values for the student group were .96 and .98 , respectively.

Please refer Ok, Back, Shanklin (2005) for further discussion about the measurement scales. 
Table 2 Characteristics of Research Participants

\begin{tabular}{|c|c|c|c|c|c|}
\hline & & \multicolumn{2}{|c|}{ Non-students $(n=286)$} & \multicolumn{2}{|c|}{ Students $(n=266)$} \\
\hline & & Frequency & Percent & Frequency & Percent \\
\hline \multirow[t]{6}{*}{ Age } & $18-24$ & 56 & 19.6 & 246 & 92.5 \\
\hline & $25-34$ & 46 & 16.1 & 11 & 4.1 \\
\hline & $35-44$ & 49 & 17.1 & 1 & 0.4 \\
\hline & $45-54$ & 65 & 22.7 & . & . \\
\hline & $55-64$ & 38 & 13.3 & . & . \\
\hline & 65 and over & 27 & 9.4 & . & . \\
\hline \multirow[t]{5}{*}{ Education } & Less than high school & 2 & 0.7 & . & - \\
\hline & High school & 28 & 9.8 & . & . \\
\hline & Some college & 89 & 31.1 & 266 & 100 \\
\hline & College graduate & 79 & 27.6 & . & . \\
\hline & Graduate degree & 84 & 29.4 & . & . \\
\hline \multirow[t]{6}{*}{ Income $^{a}$} & Less than $\$ 20,000$ & 59 & 20.6 & 155 & 58.3 \\
\hline & $\$ 20,000-\$ 39,999$ & 56 & 19.6 & 14 & 5.3 \\
\hline & $\$ 40,000-\$ 59,999$ & 55 & 19.2 & 17 & 6.4 \\
\hline & $\$ 60,000-\$ 79,999$ & 40 & 14.0 & 12 & 4.5 \\
\hline & $\$ 80,000-\$ 99,999$ & 22 & 7.7 & 13 & 4.9 \\
\hline & Over $\$ 100,000$ & 50 & 17.5 & 35 & 13.2 \\
\hline \multirow{6}{*}{$\begin{array}{l}\text { Ethnic } \\
\text { Background }\end{array}$} & African American & 15 & 5.2 & 4 & 1.5 \\
\hline & Asian & 16 & 5.6 & 3 & 1.1 \\
\hline & Caucasian/White & 241 & 84.3 & 238 & 89.5 \\
\hline & Multi-racial & 5 & 1.7 & 3 & 1.1 \\
\hline & Hispanic & 4 & 1.4 & 8 & 3.0 \\
\hline & Others & 2 & 0.7 & 2 & 0.8 \\
\hline
\end{tabular}

Note. Two to eight respondents did not indicate their personal information.

${ }^{a}$ Income is reported as the household income before tax. Students' income do not necessarily represent students' own income. 
Table 3 Complaint Intentions

\begin{tabular}{l|cc|cc|c}
\hline & \multicolumn{2}{|c|}{ Non-students $(n=286)$} & \multicolumn{2}{|c|}{ Students $(n=265)$} & \multirow{2}{*}{$t$} \\
\cline { 2 - 5 } & $M$ & $S D$ & $M$ & $S D$ & \\
\hline Complaint Intention $^{\mathrm{a}}$ & 4.17 & 1.88 & $4.15^{\mathrm{c}}$ & 1.77 & $-.18^{\mathrm{ns}}$ \\
Complaint Intention to $^{\mathrm{b}}$ & 4.76 & 1.69 & 4.50 & 1.63 & $1.86^{\mathrm{ns}}$ \\
\hline
\end{tabular}

${ }^{\text {a }}$ I am usually reluctant to complain to restaurant employees/managers regardless of how poor the service is $(1=$ strongly disagree, $7=$ strongly agree $)$.

${ }^{\mathrm{b}}$ In general, I prefer to complain to a manager than to an employee (1=strongly disagree, $7=$ strongly agree).

${ }^{\mathrm{c}}$ Values are based on 282 observations.

${ }^{\mathrm{ns}}$ Not significant at $p=.05$. 
Table 4 Initial Overall Satisfaction and Revisit Intention

\begin{tabular}{|c|c|c|c|c|c|c|c|c|c|c|c|c|c|c|}
\hline & \multicolumn{5}{|c|}{ All Restaurants $^{\mathrm{a}}$} & \multicolumn{5}{|c|}{ Brand A } & \multicolumn{4}{|c|}{ Brand B } \\
\hline & \multicolumn{2}{|c|}{$\begin{array}{l}\text { Non- } \\
\text { students } \\
(n=286)\end{array}$} & \multicolumn{2}{|c|}{$\begin{array}{l}\text { Students } \\
(n=266)\end{array}$} & \multirow[b]{2}{*}{$t$} & \multicolumn{2}{|c|}{$\begin{array}{l}\text { Non- } \\
\text { students } \\
(n=52)\end{array}$} & \multicolumn{3}{|c|}{$\begin{array}{l}\text { Students } \\
(n=63)\end{array}$} & \multicolumn{2}{|c|}{$\begin{array}{c}\text { Non- } \\
\text { students } \\
(n=23)\end{array}$} & $\begin{array}{c}\text { Students } \\
(n=47)\end{array}$ & \multirow[b]{2}{*}{$t$} \\
\hline & $M$ & $S D$ & $M$ & $S D$ & & $M$ & $S D$ & $M$ & $S D$ & $t$ & $M$ & $S D$ & $M \quad S D$ & \\
\hline $\begin{array}{l}\text { Initial Overall } \\
\text { Satisfaction }\end{array}$ & 5.68 & 1.18 & 5.60 & 1.37 & $.70^{\mathrm{ns}}$ & 5.77 & 1.00 & 5.67 & 1.01 & $.52^{\mathrm{ns}}$ & 5.67 & 1.23 & 5.86 .94 & $-.73^{\mathrm{ns}}$ \\
\hline $\begin{array}{l}\text { Revisit } \\
\text { Intention }\end{array}$ & 6.09 & 1.36 & 5.99 & 1.31 & $.94^{\mathrm{ns}}$ & 6.26 & 1.10 & 6.15 & 0.95 & $.57^{\mathrm{ns}}$ & 6.04 & 1.35 & 6.39 .68 & $-1.43^{\mathrm{ns}}$ \\
\hline
\end{tabular}

Note: Brand A and B were well-recognized national chain restaurants.

${ }^{a}$ Restaurants that participants named in the study.

${ }^{\mathrm{ns}}$ Not significant at $p=.05$. 
Table 5 ANCOVA Results of Effects of Initial Overall Satisfaction on Recovery Satisfaction

\begin{tabular}{|c|c|c|c|c|c|c|c|c|c|c|}
\hline \multirow[b]{2}{*}{ Source } & \multicolumn{5}{|c|}{ Non-students $(n=278)$} & \multicolumn{5}{|c|}{ Students $(n=260)$} \\
\hline & $\begin{array}{c}\text { Type III } \\
\text { SS }\end{array}$ & MS & $F$ & $p$ & $\eta^{2}$ & $\begin{array}{c}\text { Type III } \\
\text { SS }\end{array}$ & MS & $F$ & $p$ & $\eta^{2}$ \\
\hline Corrected Model & 194.53 & 48.63 & 27.49 & $.000^{*}$ & .29 & 162.92 & 40.73 & 24.17 & $.000^{*}$ & .28 \\
\hline Intercept & 1499.06 & 1499.16 & 847.39 & $.000^{*}$ & .76 & 1036.79 & 1036.79 & 615.20 & $.000^{*}$ & .71 \\
\hline $\begin{array}{l}\text { Recovery } \\
\text { Scenarios }\end{array}$ & 189.79 & 189.79 & 107.28 & $.000^{*}$ & .28 & 107.32 & 107.32 & 63.68 & $.000^{*}$ & .20 \\
\hline $\begin{array}{l}\text { Initial Overall } \\
\text { Satisfaction }\end{array}$ & 13.41 & 4.47 & 2.53 & .058 & .03 & 39.20 & 13.02 & 7.75 & $.000^{*}$ & .08 \\
\hline Error & 482.98 & 1.77 & & & & 429.75 & 1.69 & & & \\
\hline Total & 7448.67 & & & & & 6576.67 & & & & \\
\hline Corrected Total & 677.50 & & & & & 592.67 & & & & \\
\hline
\end{tabular}

Note. $* p<.001$

Model: Intercept + Recovery scenarios + Initial Overall Satisfaction

Covariate: Recovery scenarios

Initial overall satisfaction is categorized into four groups (see figure 1). 
Table 6 Regression Coefficients

\begin{tabular}{l|cccc|cccc}
\hline \multirow{2}{*}{ Dimensions of Justice } & \multicolumn{4}{|c|}{ Non-students $(n=286)$} & \multicolumn{4}{c}{ Students $(n=266)$} \\
\cline { 2 - 9 } & $\mathrm{B}$ & $S E$ & $\beta$ & $t$ & $\mathrm{~B}$ & $S E$ & $\beta$ & $t$ \\
\hline Procedural Justice & .345 & .047 & .351 & $7.36^{*}$ & .143 & .051 & .139 & $2.83^{*}$ \\
Distributive Justice & .375 & .046 & .351 & $8.24^{*}$ & .561 & .053 & .517 & $10.53^{*}$ \\
Interactional Justice & .278 & .050 & .268 & $5.61^{*}$ & .306 & .051 & .301 & $5.99^{*}$ \\
\hline
\end{tabular}

Dependent Variable - Service recovery satisfaction

${ }^{*} p<.001$

Note: Because this study was intended to compare measures of non-student and student groups, it was desired to have the composition of age categories as close as possible to that of general restaurant customers. We compared the age distribution in our study with the national age distribution reported in the U.S. Census (U.S. Census Bureau, 2005). The percentage of the age category of 18 to 24 in the customer sample in this study was higher than the national average, and the percentage of the age category of 65 years and over was lower than reported in the U.S. Census 2000 . Then, we randomly selected 17 respondents who reported themselves as college students aged 18 to 24 and combined with the student group. All data analyses were redone and found no noticeable differences. In testing of dimensional roles of justice, with the new set of data, standardized coefficient $(\beta)$ of distributive justice of non-student group was reduced to .343 where standardized coefficient of procedural justice was .367 . The results are consistent with the findings in the student group that distributive justice is the most significant factor in determining students' recovery satisfaction. 
Table 7 Regression Estimates of IS and RS on Post-recovery Overall Satisfaction

\begin{tabular}{l|cccc|ccccc}
\hline Positive Recovery Satisfaction Group \\
\hline & \multicolumn{7}{|c|}{ Non-students $(n=206)$} & \multicolumn{4}{c}{ Students $(n=181)$} \\
\cline { 2 - 10 } & $\mathrm{B}$ & $S E$ & $\beta$ & $t$ & $\mathrm{~B}$ & $S E$ & $\beta$ & $t$ \\
\hline Initial Overall Satisfaction (IS) & .549 & .046 & .590 & $12.05^{*}$ & .491 & .044 & .554 & $11.24^{*}$ \\
Recovery Satisfaction (RS) & .437 & .066 & .326 & $6.67^{*}$ & .509 & .062 & .407 & $8.25^{*}$ \\
\hline
\end{tabular}




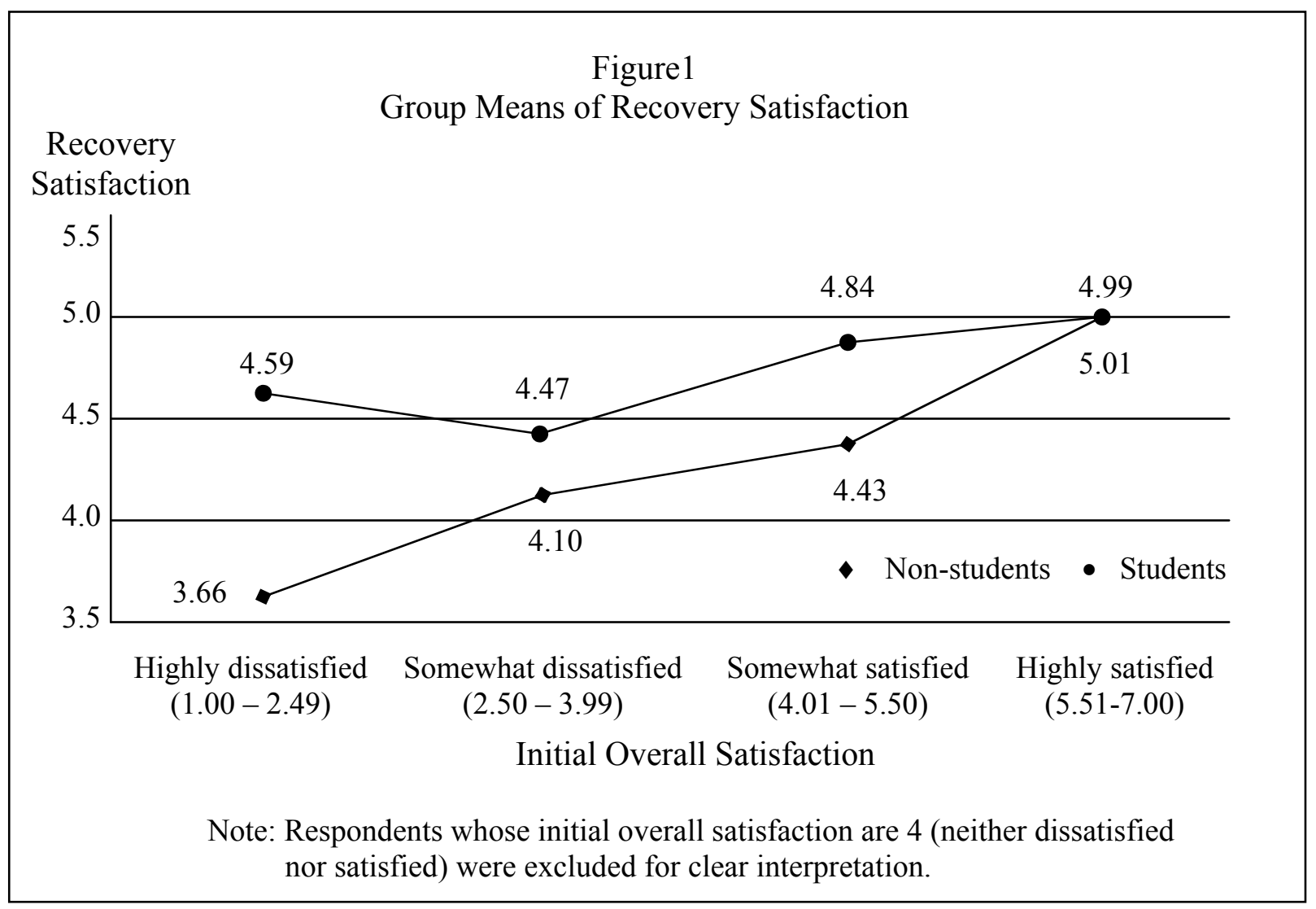

